\title{
Hvordan kan digitale læringsressurser bidra til økt studentaktivitet i klasserommet?
}

\author{
Cecilie Lønn $^{\mathrm{a}}$ og Eli-Marie Danbolt Drange ${ }^{\mathrm{b}}$ \\ a Universitetet i Oslo \\ b Universitetet i Agder
}

\section{Innledning}

Stadig mer tilgjengelig og brukervennlig teknologi har resultert i økt fokus på digitale læringsressurser til bruk i undervisning og læring. Med digitale læringsressurser mener vi i denne sammenhengen ulike typer ressurser som brukes i et læringsarbeid og som er tilgjengelige $i$ et digitalt format. Det er ikke gitt at økt bruk av digitale læringsressurser fører til mer læring, det er derfor viktig og nødvendig å følge elever og studenters læringsprosess tett når en velger å ta i bruk denne typen læringsressurser. I prosjektet Litteratur på nett, som vi presenterer i denne artikkelen, har vi utviklet digitale læringsressurser som støtte for studenter i arbeidet med å lese litterære tekster på et fremmedspråk. I dette utviklingsarbeidet har vi prøvd ut og vurdert ulike typer læringsressurser og vi har sett på hvordan ressursene kan kombineres med tradisjonell klasseromsundervisning for å skape et godt læringsmiljø. Gjennom hele utviklingsarbeidet har studentenes faktiske læringsprosess stått sentralt med fortløpende tilbakemeldinger fra studentene og vurdering av studentenes arbeider. Det at vi har utviklet ressursene parallelt med å bruke dem i undervisningen, har ført til at vi har kunnet gjøre justeringer underveis i forhold til de planlagte digitale ressursene og også fått ideer til utvikling av nye ressurser.

I denne artikkelen vil vi beskrive prosessen rundt utviklingen av de digitale læringsressursene og hvordan disse er blitt en integrert del av faglærerens didaktikk samtidig som de har bidratt til økt deltakelse fra studentene. Selv om ressursene som beskrives her er utviklet som støtte til ansikt-til-ansikt undervisning i et emne i spanskspråklig litteratur på universitetsnivå, er erfaringene overførbare både til andre fag og til undervisning på lavere nivåer. Ved å beskrive våre erfaringer med å utvikle og integrere digitale læringsobjekt i en undervisningssituasjon ønsker vi å bidra til refleksjon rundt ulike typer digitale ressurser og hvordan de kan kombineres med ansikt-til-ansikt undervisning for å skape gode læringsmiljø med økt studentaktivitet.

De digitale ressursene som omhandles i denne artikkelen er utviklet som støtte til emnet «Litteratur og kultur i Latin-Amerika og Spania» som inngår i Spansk årsstudium ved Universitetet i Agder (UiA) og Høgskolen i Telemark (HiT). Utviklingsarbeidet har fått støtte fra Norgesuniversitetet, Det Digitale Universitet (DDU) på UiA og HiT. Innholdet i 
ressursene beskrives nærmere i artikkelen «Litteratur på nett» Om utvikling av digitale læringsressurser til bruk i litteraturundervisning i spansk" (Lønn \& Drange 2013), mens vi i denne artikkelen vil se mer på hvordan ressursene er blitt integrert i studentenes læringspraksiser og i hvilken grad de bidrar til økt aktivitet. Først vil vi sette bruk av digitale ressurser og undervisning av litteratur på et fremmedspråk i en større ramme. Deretter vil vi beskrive konteksten de konkrete læringsressursene inngår i og den utviklingsprosessen vi har vært igjennom. Til slutt vil vi reflektere rundt resultatene av denne prosessen og hvordan våre erfaringer er relevante i en større sammenheng.

\section{Teoretisk perspektiv}

\subsection{Utdanningskvalitet og digitale ressurser i undervisning og læring}

De siste årene har det vært et økt fokus på utdanningskvalitet. Framtiden defineres som et kunnskapssamfunn der kompetanse blir stadig viktigere sammen med evnen til livslang læring. Dette stadfestes blant annet i et av satsingsområdene i Bolognaprosessen:

I fremtidens Europa, bygd på et kunnskapsbasert samfunn og en kunnskapsbasert økonomi, er strategier for livslang læring nødvendige for å kunne møte konkurranseutfordringene og bruken av ny teknologi og for å styrke sosiale bånd, like muligheter og livskvalitet. (Kunnskapsdepartementet, uå)

I denne sammenhengen blir det viktig å kunne måle effekten av undervisning gjennom å definere konkrete læringsmål for hver aktivitet. I Norge ser vi at fokuset på økt kvalitet i undervisningen er satt på dagsorden igjennom Kvalitetsreformen og opprettelsen av NOKUT i 2003. Utdanningsinstitusjonene må definere et tydelig læringsutbytte for hvert studieprogram i henhold til Nasjonalt kvalifikasjonsrammeverk for høyere utdanning.

Læringsutbyttebeskrivelsene skal vise til hvilken kunnskap studentene vil tilegne seg i studiet, hvilke ferdigheter de vil kunne oppøve og hva de kan oppnå av generell kompetanse.

Kvalifikasjonsrammeverket viser også til en progresjon med økt kompleksitet i læringsutbyttet på høyere nivå i utdanningsløpet (Kunnskapsdepartementet, 2011). Et av formålene med kvalifikasjonsrammeverket kan sies å være å "dreie oppmerksomheten fra undervisning til læring - fra innsatsfaktorer til læringsutbytte" (Kunnskapsdepartementet, 2011: 9, kursiv i original). I dagens utdanningssamfunn er det altså viktig å kunne vise til at studentene oppnår det læringsutbyttet som er definert i et gitt fag, og det er en dokumentasjon på at studentene lærer.

Kvalitetsbegrepet settes ofte også i sammenheng med økt bruk av teknologi, og det har vært knyttet store forventninger til at innføring av teknologi og digitale ressurser i høyere utdanning skal kunne føre til mer læring og da også høyere kvalitet på undervisningen (Ørnes, Wilhelmsen, Breivik, \& Solstad 2011, s. 77). Ørnes et. al. (ibid) fremhever videre at forventningene handler om at IKT skal bidra til nye undervisnings- og læringsformer, og en mer studentaktiv læring. På tross av disse forventningene, er det fortsatt også en del skepsis knyttet til gevinsten av bruk av digitale ressurser i en undervisningssituasjon. Selv om de fleste utdanningsinstitusjoner har investert mye i infrastruktur knyttet til IKT, er det fortsatt langt igjen før potensialet i en pedagogisk bruk av IKT er utnyttet til fulle (jf. Granberg 2011).

Med infrastrukturen på plass, er det også kortere vei til å tilby nettbaserte utdanninger.

Det nyeste innen dette feltet er de såkalte MOOC, som tilbyr gratis nettstudier til store grupper. Andre konsentrerer seg om campusundervisning, og inkluderer digitale læringsressurser i varierende grad. Kombinasjonen av ansikt-til-ansikt undervisning i 
klasserommet og digitale læringsaktiviteter kalles gjerne for «blended learing» (Garrison \& Kanuka 2004, s. 96, Ginns \& Ellis 2007). Det varierer hvor mye og hvilken type læringsaktiviteter som er nettbaserte, men hovedarenaen for denne typen undervisning er fortsatt klasserommet og de digitale læringsressursene vil være en støtte eller utvidelse av denne undervisningen.

Det er åpenbart at bruk av IKT i undervisningen ikke nødvendigvis fører til bedre kvalitet i seg selv, samtidig som kvalitetsbegrepet er vanskelig å definere. Likevel vil innføring av IKT kunne føre til prosesser både hos undervisere og studenter som øker kvaliteten på undervisningen og resulterer i mer læring. Mye av forskningen rundt bruk av IKT i undervisningen har konsentrert seg om å beskrive ulike metoder, mens færre studier har målt studentenes opplevelse av studiene og hvordan læringsutbyttet har vært (López-Pérez 2011, s. 818). I rapporten Digital tilstand 2011 konkluderer Ørnes et. al. (2011, s. 113) med at "Digitale verktøy og medier er viktig for studentenes opplevelse av læring og kvalitet". En opplevelse av læring og kvalitet kan bidra til økt motivasjon hos studentene som videre kan føre til faktisk læring (cf. López-Pérez 2011). López-Pérez (2011, s. 824) viser til at i deres eksperiment ved Universitetet i Granada opplevde de at e-læringsaktivitetene fungerte som støtte og komplement til ansikt-til-ansikt-undervisningen. Slik ligger det potensiale for å endre eksisterende læringspraksiser i en ny kontekst som kombinerer ansikt-til-ansiktundervisning med digitale læringsressurser (López-Pérez 2011). I prosjektet Litteratur på nett har vi tatt dette potensialet på alvor når vi har prøvd ut ulike typer digitale ressurser og kombinert dem med klasseromsundervisning.

\subsection{Hvordan og hvorfor studere litteratur i fremmedspråksundervisningen?}

Hvordan man definerer språklæring og hva som er målet med undervisningen i fremmedspråk, vil være avgjørende for hvilken innfallsvinkel man har ved utvikling og bruk av digitale læringsressurser i dette faget. I tidligere tider konsentrerte fremmedspråksundervisningen seg hovedsakelig om å lære de klassiske språkene latin og gresk, og fokus lå på å beherske språkene skriftlig (Bjørke, Dypedal \& Myklevold 2014, s. 20). Etter hvert som de klassiske språkene er byttet ut med moderne fremmedspråk som fransk, tysk og spansk, er også fokus flyttet over til å beherske kommunikasjon. Fram til 1980-tallet ble det å undervise i litteratur i fremmedspråkundervisningen sett på som en selvsagt aktivitet. En redegjørelse for og undersøkelse av hvorfor man skulle undervise i litteratur, lot derfor til å være tilnærmet unødvendig. Litteraturens plass var selvskreven. Men i løpet av de tre siste tiårene har fokuset for litteraturundervisningen dreid litt. Det er blitt lagt mer vekt på å utvikle kommunikativ kompetanse, og den tradisjonelle litteraturundervisningen (som ofte har vært preget av skriftlighet) er blitt utfordret og skjøvet litt ut på sidelinjen (Hansejordet 2012). På 1980-tallet oppstod det imidlertid diskusjoner omkring hvordan man skal undervise litteratur i fremmedspråk og hvorfor (Carter 1991).

Carter peker på tre ulike tilnærminger til litteratur i fremmedspråkundervisningen. Disse tre modellene består av a) en språklig tilnærming b) en kulturell tilnærming, og c) en tilnærming hvor personlig utvikling står i fokus. Vi vil i det følgende gjøre rede for disse tre begrepene til Carter, og drøfte hvilke av disse tilnærmingsmodellene vi finner det viktig å framheve i vårt prosjekt og i vår undervisning.

\section{Språklig tilnærmingsmodell}

Når det gjelder den språklige tilnærmingsmodellen til litteratur i

fremmedspråkundervisningen framhever Carter at mange lærere vil begrunne sin bruk av litteratur i undervisningen med at det fremmer og støtter språkinnlæring. Han hevder videre at et uheldig resultat av en undervisning hvor den språklige tilnærmingen står i fokus kan være 
at man havner i en undervisning preget av mekanisk innlæring og følgelig også en demotiverende praksis. Carter påpeker at det er viktig at språkaktivitetene ikke erstatter det genuine engasjementet for selve teksten:

Such an argument misunderstands the nature of language in literature and may even result in mechanistic and demotivating teaching practices which substitute language activities in place of a genuine engagement with the work as literature and will probably have the detrimental effect of spoiling any pleasure the poem or story might have given (Carter, 1991: 2).

Carter minner oss videre om at litteratur er laget av språk, og at lesing av litteratur vil høyne studentenes kompetanse til å forstå litteratur. Vårt fokus i litteraturundervisningen i fremmedspråk tar utgangspunkt i språklige vendinger og termer for å gi en inngang til litteraturen og den litterære teksten - men dette er ment som en tilrettelegging; som et hjelpemiddel for å kunne oppnå en kompetanseheving hos studentene, altså, at deres kompetanse for å forstå litteratur høynes. Vi anser også den språklige kompetansen som den grunnleggende som studentene først må ha tilegnet seg, og vi omtaler den som det første nivået i læringsprosessen.

\section{Kulturell tilnærmingsmodell}

Den kulturelle tilnærmingsmodellen understreker verdien av tankene som kommer til uttrykk gjennom litterære tekster (accumulated wisdom). Denne modellen vil kunne istandsette studenter til å forstå og verdsette ideologiske forskjeller:

Teaching literature within a cultural model enables students to understand and appreciate cultures and ideologies different from their own time and space and to come to perceive tradition of thought, feeling, and artistic form within the heritage the literature of such cultures endows (Carter, 1991:1).

I vår tilnærming i litteraturstudiet finner vi det nærliggende å fokusere på det kulturelle aspektet som Carter her trekker fram. Litterære tekster tilbyr gode redskaper for å gi studentene en inngang til kulturen slik den er i de ulike spansktalende landene. Litterære tekster gir særegne innblikk i både tradisjoner, tankesett, emosjoner og kunstnerisk form. Vår oppfatning er at studentene klarer å gripe en større del av kulturen gjennom tilegnelse av og arbeid med litterære tekster.

\section{Personlig utviklingsmodell}

Modellen for personlig utvikling beskrives blant annet på denne måten av Carter: "One of the main goals for teachers who are primarily committed to a personal growth model of literature teaching is to try to help students to achieve an engagement with the reading of literary texts" (Carter, 1991: 3). Carter påpeker at dette engasjementet er et engasjement som også vil gi seg til kjenne utenfor klasserommet, og at det bidrar til studentenes selvutvikling og deres framtidige måte å møte tekster på. For å oppnå et slikt engasjement, er det blant annet viktig å velge tekster med omhu for undervisningen, sier Carter. I vår undervisning tar vi hensyn både til de akademiske kravene (med hensyn til blant annet språklig nivå, anerkjennelse av de litterære verkene, litterær kvalitet, etc.) og å ha et utvalg av tekster vi tror studentene kan oppleve som interessante og meningsfulle. Vi vil også tillegge at vi tror lærerens personlige engasjement og entusiasme for de aktuelle tekstene vil være avgjørende for om studentene opplever litterært engasjement, eller ei.

I vår tilnærming til litteraturundervisning i fremmedspråk inngår de tre omtalte modellene til Carter i et samspill med hverandre. Vi tror det er vesentlig å vektlegge både den 
språklige vinningen litterære tekststudier gir, det kulturelle aspektet ved tekstene - og at studentene opplever engasjement og følgelig da personlig utvikling (en utvikling som fortsetter utenfor klasserommet og etter at studiet er avsluttet).

\section{Kontekst}

\subsection{Utfordringer knyttet til det å undervise litteratur i spansk som fremmedspråk}

I studiet av spanskspråklig litteratur forventes det at studentene skal kunne lese autentiske litterære tekster. Tekstene har et høyt nivå både når det gjelder språk og innhold. De er skrevet av anerkjente spanskspråklige forfattere, noen av dem også nobelprisvinnere som for eksempel Gabriel García Márquez. Dette gjør at tekstene kan være vanskelige å forstå og trenge gjennom også for personer som har spansk som morsmål. I tillegg er studentenes språklige nivå divergerende. Nivået strekker seg fra tilnærmet nybegynnernivå og opp til morsmålsbrukere. Spørsmålet som naturlig melder seg er hvordan og for hvem vi i størst grad skal tilrettelegge undervisningen.

Studentene på lavest nivå har naturlig nok ofte mer enn nok med å forstå hovedinnholdet og grunnleggende ord og uttrykk i de litterære tekstene. I tillegg er tekstene ofte komplekse på grunn av ironi, kulturelle referanser man ikke uten videre kan gripe, intertekstualitet, særegne ord og uttrykk for den lokale varianten av spansk i det landet teksten utgår fra, dobbel betydning, sarkasme, etc. Faglærer har ofte lite tid til å gjennomgå tekstene, og det er vanskelig å trenge igjennom teksten for å bringe studentene opp på et nivå der de kan bidra med egen refleksjon. Til tross for at studentene kanskje har forsøkt å lese teksten på egenhånd først, må faglærer likevel bruke mye av tiden i undervisningen med studentene for å trenge gjennom tekstens første nivå. Man kan derfor i en tradisjonell undervisningssituasjon oppleve at man ved gjennomgang av pensumtekster faktisk ikke kommer videre $\mathrm{i}$ arbeidet med teksten enn til det å forstå det rent språklige innholdet.

\subsection{Hva er læringsutbyttet i emnet "Litteratur og kultur i Latin-Amerika og Spania"?}

Et sentralt mål for undervisningen vår er at studentene skal videreutvikle og øke sin kompetanse i fremmedspråket (jf. Carters språklige modell over). Vi mener at mest mulig naturlig input på fremmedspråket bidrar til økt språkkompetanse (jf. Krashen 1985, 1987), og vi bruker hovedsakelig spansk i all undervisning og som hovedspråk i de digitale læringsressursene. Læringsutbyttet i litteraturfaget handler også om å kunne sette tekstene inn i en større sammenheng, både i forhold til samfunnet teksten utgår fra og tekstens forhold til andre tekster. Videre er det et mål at studentene blir satt i stand til å uttrykke egne meninger og holdninger til innholdet i tekstene. Slik blir eksamen altså ikke en vurderingssituasjon som først og fremst belønner at studentene gjengir faglærerens tolkning av tekstene. Det verdsettes snarere at studentene selv har kommet fram til, og kan gi uttrykk for, hva de mener om tekstenes innhold og tekstenes diskurs. I denne sammenhengen må studentene også kunne uttrykke seg på fremmedspråket, selv om fokus og innhold i emnet hovedsakelig handler om litterær kompetanse.

Å jobbe med litteratur med studenter åpner opp for mange muligheter. Når studentene forstår tekstene og klarer å forholde seg til dem i tillegg til å uttrykke egne reaksjoner, følelser og tanker rundt dem, oppnår studentene også å føle seg berørt av noe. Når man blir berørt og / eller utfordret av noe (for eksempel av en annerledes kulturell tankemåte og et fremmedartet univers), opplever man utvikling - og som en konsekvens av dette kan danning og personlig 
utvikling skje. Målet med å studere litteratur på universitetsnivå bør i ytterste konsekvens være å bidra til studentenes danning og personlige utvikling (jf. Carter). Litterære tekster egner seg utmerket til å kunne utfordre studentene, både deres personlige verdensforståelse og deres kulturelle plattform. Å oppleve brytning og å bli utfordret på denne måten blir av oss betraktet som ønskelig, sunt og dannende. Ingen svar blir gitt. Det er studentene som må finne sine egne svar. I dette ligger det et stort potensial for egenrefleksjon og egenutvikling. Dette ser vi på som positivt og spennende, og i tråd med ideen om å legge til rette for livslang læring (jf. 2.1).

\section{Hva skjer når digitale læringsressurser tas i bruk?}

Utgangspunktet vårt for å utvikle digitale læringsressurser i emnet «Litteratur og kultur i Latin-Amerika og Spania» var å gi studentene en støtte i arbeidet med de autentiske litterære tekstene på spansk. Da vi startet prosjektet stod det ikke klart for oss at de digitale ressursene ville komme til å skape en egen dynamikk i læringsprosessen og fungere som en slags katalysator for utvikling av nye måter å undervise og lære på. Dette oppdaget vi etter hvert. I det følgende vil vi beskrive den prosessen vi har gått igjennom mens vi har utviklet de digitale læringsressursene og hvordan denne prosessen har bidratt til å skape nye læringsmåter og ført til økt studentaktivitet.

\subsection{Kartlegging av studentenes bruk av digitale læringsressurser}

Emnet «Litteratur og kultur i Latin-Amerika og Spania» er gjennomført tre ganger i sin nåværende form, første gang våren 2012, så våren 2013 og siste gang våren 2014. I denne perioden har vi samlet inn informasjon om studentenes bruk av de digitale læringsressursene, i tillegg til at vi har kartlagt eksamensresultater. Våren 2012 gjennomførte vi en spørreundersøkelse med spørreskjema i en undervisningstime midtveis i semesteret.

Hensikten med denne undersøkelsen var å finne ut i hvor stor grad studentene brukte de digitale læringsressursene uten at de var introdusert spesielt. Det ble også gjennomført fokusgruppeintervjuer med to grupper studenter denne våren, i tillegg til at eksamensbesvarelsene ble analysert (se Drange og Tønnessen, under arbeid).

Våren 2013 bygget vi på erfaringene fra første gangs bruk av de digitale læringsressursene (våren 2012), og vi valgte å introdusere ressursene spesielt første undervisningstime. Ved slutten av semesteret ble studentene bedt om å svare muntlig på en rekke spørsmål knyttet til deres bruk av de digitale ressursene i emnet. Svarene ble tatt opp som egne lydfiler i en språklab, og disse er transkribert i ettertid. I den siste gjennomgangen av emnet, har vi ikke samlet inn data om studentenes bruk av de digitale ressursene, men vi har fått utelukkende positive tilbakemeldinger fra studentene muntlig, inkludert referanser til nytten av de digitale ressursene i studentevalueringer, etc. I alle tre gjennomgangene kan vi vise til gode eksamensresultater, som viser at studentene har oppnådd ønsket læringsmål.

\subsection{Digitale læringsressurser gir oversikt og struktur}

Hovedelementet i de digitale læringsressursene er det vi har kalt for videodialoger. En videodialog er en faglig samtale om et tema mellom to faglærere, og samtalen er videofilmet. I videodialogene i det emnet som behandles i denne artikkelen, handler hver samtale om en av de litterære tekstene på pensum, og samtalene er på spansk. Når samtalene er filmet, er det lettere for studentene å få med seg innholdet selv om det er på fremmedspråket, siden filmen kan stoppes og spilles om igjen etter behov. En samtale mellom to personer er også lettere å forstå enn en muntlig presentasjon, da en muntlig presentasjon som regel vil ligge nærmere 
skriftspråket og følgelig ha en høyere leksikal tetthet (Halliday, 1989, s. 62). Med lavere leksikalsk tetthet, vil det være færre ukjente ord som kan ødelegge forståelsen av språket. I tillegg støttes samtalen av tilbakemeldingssignaler og ikke-verbal kommunikasjon som gester og ansiktsuttrykk.

I videodialogene presenteres de litterære tekstenes story. I tillegg gjøres det rede for stoff vi anser som sentralt for å oppnå en høyere grad av refleksjon. Dette kan for eksempel dreie seg om en kort gjennomgang av forfatterens samtid og den litterære tradisjonen teksten utgår fra; det kan være blikk på grunnleggende aspekter ved teksten med anvendelse av teoretisk språk som en modell for studentene; det kan være faglærers egne, ofte mer personlige tanker omkring teksten - med appell til studentene om å gjøre seg sine egne tanker.

Vi har også utarbeidet digitale ordlister for hver enkelt litterære tekst for å hjelpe studentene til å forstå språket i tekstene. Vi anser disse ordlistene for primært å være et redskap til hjelp for å komme gjennom det første nivået i læringsprosessen (det språklige nivået), nemlig å kunne forstå hva som skjer i teksten (å forstå tekstens story). For å lære ordene (oppnå produktiv ordkunnskap, jf. Bjørke 2014), er det ifølge vår erfaring nødvendig med mer enn "kun" ordlister. Ordlistene inneholder ordet i sin grunnform, en kolonne med ordet slik det forekommer i teksten hvis det ikke er i grunnformen og en kolonne med ordet oversatt til norsk. Gjennom å anvende ordlistene og se videodialogene, blir studentene gitt en realistisk mulighet til å stille mer forberedt til undervisning. Dette gjør at både studenter som har lave forkunnskaper i spansk og morsmålsbrukere kan forberede seg med utgangspunkt i det nivået de har. Videodialogene vil for eksempel kunne utfordre morsmålsbrukere når det gjelder å tilegne seg et teoretisk språk om litteratur og reflektere selv, og de kan også utfordre $i$ forhold til å bygge opp faktaorientert kunnskap om tekstens forfatter og samtid. På grunnlag av dette mener vi at videodialogene kan være nyttige og fremme læringsutbytte for studenter på ulike nivåer. Tilbakemeldinger fra studentene underveis underbygger denne oppfatningen:

Student2012: 《Jeg synes pensum er vanskelig, men er mye lettere å forstå gjennom videosekvensen.»

Student2013-01: «Nettressursene har vært veldig viktige for meg i forhold til å kunne forstå tekstene bedre.»

Student2013-02 «[Nettressursene er] nyttige fordi det er lettere å forstå tekstene, $\mathrm{i}$ tekstene kan det være mange vanskelige ord, og dialogene gjør det lettere å forstå hovedinnholdet og da er det lettere å forstå tekstene.»

Faglærer har på forhånd gjort noen valg i forhold til hva man skal arbeide med når det gjelder litterær analyse. Gjennom dette blir målene for faget konkretisert, jf. betydningen av at studentene klart skal vite hva som er læringsmålene. Fagets læringsutbytte blir i første omgang gjort klart gjennom fagets emnebeskrivelse, i kombinasjon med faglærers vinkling av faget. Ettersom faget i seg selv heter" Litteratur og kultur i Latin-Amerika og Spania" legger dette også en del premisser for innfallsvinkelen. Faglærer legger (innenfor rammen av det som oppleves som naturlig) vekt på de samme aspektene i hver samtale, og gjennom dette vil studentene i stigende grad danne seg et bilde av læringsmålene - og dermed også hva som forventes av dem til eksamen. Vi har med andre ord opplevd at de digitale ressursene strukturerer arbeidet med å klargjøre læringsmålene og at de er med på å bygge opp undervisningen rundt læringsmålene. I siste instans bidrar de også til at man lager en eksamen som står i samsvar med læringsmålene (jf. 2.1).

\subsection{Digitale læringsressurser skaper nye praksiser}


Når deler av de digitale ressursene forelå, måtte vi først bruke litt tid på å få studentene til å oppdage at ressursene faktisk var der for dem. Vi gjentok en del ganger for studentene at de kunne gå inn på anvist nettside og bruke ressursene som lå der. Selv om vi selv mente at vi ga nokså eksplisitt beskjed om dette flere ganger, forstod vi etter hvert at vi måtte gjøre beskjeden enda tydeligere - ettersom det viste seg at det var flere enn antatt som fortsatt ikke gikk inn og tok ressursene i bruk (se Drange og Tønnessen, under arbeid). Vi gjorde disse tiltakene for å få studentene inn $\mathrm{i}$ en vane med å bruke ressursene:

- $\quad$ Vi trakk ressursene inn i selve undervisningstiden (kun i startfasen).

- V Vi gjennomførte en spørreundersøkelse før og etter bruken av disse ressursene i timene, for å kartlegge studentenes bruk og deres oppfatning av det å jobbe med ressursene.

- $\quad$ Vi innførte obligatoriske prøver på læringsplattformen Fronter hvor studentene måtte svare på spørsmål de bare kunne svare på gjennom å ha sett videodialogen. (Studentene kunne altså ikke svare på spørsmålene kun gjennom å ha lest den teksten det ble snakket om; vi ville tvinge fram at studentene skulle lytte til dialogen a) gjennom å gjøre oppgaven obligatorisk og b) gjennom å lage spørsmål man bare kunne vite svaret på gjennom å ha lyttet til dialogen.

Etter at vi hadde gjennomført disse tiltakene, merket vi at studentene brukte ressursene mer konsekvent og tilsynelatende mer rutinemessig. Dette sjekket vi gjennom at vi spurte om studentene hadde anvendt ressursene. Vi fikk bekreftende svar på dette. I tillegg var det flere som begynte å etterlyse materiell på tekster hvor vi ennå ikke hadde utviklet ressurser, som for eksempel prøver til de dialogene som ikke hadde dette. Dette bekreftet at studentene hadde begynt å bruke ressursene.

På spørsmål om hvordan studentene bruker de digitale ressursene, svarer de fleste studentene at de bruker de veldig mye, og da spesielt i forkant av den aktuelle forelesningen. I tillegg trekker noen studenter fram at de bruker dem som repetisjon fram mot eksamen:

Student2013-03: «Mye, ser videoene flere ganger før forelesningen og i etterkant fram mot eksamen.»

\section{Videodialogens plass i forhold til undervisningen}

Målet vårt med videodialogene var at studentene skulle bruke dem som en forberedelse til undervisningen i klasserommet. Som beskrevet i avsnittet over, måtte vi arbeide fram rutiner for å venne studentene til å se videodialogene i forkant av undervisningen. Når studentene fikk innarbeidet en vane med å bruke de digitale ressursene til forberedelse før timene, så vi at de fungerte som en støtte til selve undervisningen; de bidro til at man kom lenger i selve undervisningssituasjonen og fungerte altså som en indirekte hjelp til undervisningen. Sammenlignet med tidligere erfaringer med tilsvarende faglig innhold, men uten digitale læringsressurser, viste studentene en større evne til å ta poenger og reflektere rundt innholdet $\mathrm{i}$ tekstene i selve undervisningssituasjonen. Rent konkret kunne det arte seg slik at faglærer kunne henvise til innhold fra videodialogene, og da kunne studentene nikke bekreftende (eller på andre måter uttrykke forståelse), i tillegg til at de kunne diskutere og kommentere videoens innhold og reflektere $\mathrm{i}$ forhold til det som hadde blitt sagt der - i samhold med stoff som ble tatt opp i undervisningen.

På denne måten inngikk videodialogene i en ny dialog med selve undervisningssituasjonen. I klasserommet ble videodialogenes innhold til dels gjentatt for å styrke forståelsen av vanskelig stoff, i tillegg til at det ble referert til og gjort til gjenstand for en videre metarefleksjon. Gjennom denne prosessen har videodialogen funnet sin plass $i$ undervisningen. Den brukes i et samspill mellom faglærer og studenter, og den brukes for å 
styrke innlæringen og øke forståelsen, i tillegg til at den bidrar til at studentene blir mer aktive i selve undervisningssituasjonen.

På spørsmål om hva studentene lærer mest av, nettressurser eller forelesning, svarer de fleste at de lærer mest av forelesningene, men at nettressursene bidrar til økt forståelse og økt utbytte av forelesningene:

Student2013-04: 《Får mer ut av forelesningen når jeg er forberedt.»

Student2013-05: 《Jeg lærer godt av begge deler, i forelesningene kan man stille spørsmål, men jeg liker å høre på videodialogene også.»

Student2013-06: «Absolutt best med forelesninger, men kombinasjonen er fin, med nettressurser kan en gå tilbake når en vil.»

\section{Samsvar mellom undervisning og vurdering}

Da vi skulle utvikle de digitale læringsressursene, ble vi nødt til å skape en bedre struktur i undervisningen og også tydeliggjøre målene for hva studentene skulle lære. Gjennom prosessen med å tydeliggjøre læremål, undervisning og eksamensmål, tvang det seg fram en endring i vår egen måte å oppfatte eksamensoppgavene på. I det første året vi hadde eksamen med et kull som hadde brukt de digitale ressursene, oppdaget vi i etterkant at eksamensoppgavespørsmålene ikke stod i tilstrekkelig samsvar med de læremålene vi hadde skissert opp i løpet av semesteret. Eksamensspørsmålene som ble utarbeidet i dette første året bar preg av å være for lukkede. I løpet av studieåret hadde vi lagt opp til at studentene skulle reflektere rundt tekstene. Men istedenfor å stille flere spørsmål som inviterte til refleksjon, ble studentene på eksamen stilt konkrete spørsmål som krevde konkrete svar. Vi oppdaget at dette ikke stod helt i samsvar med vår opprinnelige intensjon. Som konsekvens av denne oppdagelsen endret vi formen på spørsmålene studentene fikk til eksamen påfølgende år. Da laget vi spørsmål som var mer åpne, hvor studentene i større grad ble invitert til å reflektere. Gjennom dette opplevde vi at arbeidet vårt var blitt mer transparent, mer oversiktlig og mer i tråd med våre egne intensjoner for faget.

\section{Bidrar digitale læringsressurser til å skape nye læringsmåter og økt studentaktivitet?}

I utgangspunktet var det en utfordrende oppgave for studentene å oppnå læringsutbyttet i faget på grunn av store variasjoner i forkunnskaper i spansk, begrenset tid og et stort og krevende pensum. Ved hjelp av de digitale læringsressursene i kombinasjon med ansikt til ansiktundervisning ble dette arbeidet overkommelig. For både faglærer og studenter ble læringsarbeidet annerledes enn hva det ville ha vært uten de digitale ressursene. Som faglærere, kunne vi til enhver tid henvise til digitale ressurser hvor studentene kunne få hjelp - enten til forberedelse eller til videre arbeid. Studentene var ikke fullstendig overlatt til seg selv. De digitale ressursene viste retningen i et bredt og utfordrende materiale - og de digitale ressursene inngikk i et fruktbart samspill mellom faglærer, studenter, ansikt-til-ansikt undervisning og fagstoff på en slik måte at det skapte et godt læringsmiljø.

Å jobbe med utvikling av digitale læringsressurser parallelt med å bruke dem i undervisning, har også ført til at nye behov og ideer til digitale ressurser har oppstått. Gjennom å bruke videodialogene, oppstod blant annet behovet for å utvikle en komponent vi kalte "Nøkkelord" (se beskrivelse nedenfor). Vi ser altså at arbeidet med de digitale 
ressursene i kombinasjon med ansikt til ansikt-undervisning bringer med seg en form for gjensidig påvirkning. Samtidig bidrar nye praksiser til at digitale ressurser blir brukt på nye måter. Slik skaper bruk av digitale læringsressurser i kombinasjon med ansikt-til-ansikt undervisning nye undervisnings- og læringsmåter.

\section{Videodialogene som felles referanseramme}

I tillegg til å være en støtte i forberedelsen av en tekst, ble dialogene også ble brukt i utstrakt grad i forbindelse med repetisjon av stoff. Studentene lærte seg enkelte fraser og ord fra noen av tekstene. Dette gjenspeilte seg i ulike sammenhenger i undervisningen. Når faglærer sa enkelte setninger, kunne flere av studentene smile og nikke gjenkjennende. Enkelte setninger og enkelte oppfatninger om stoffet hadde blitt sagt og tatt opp til drøfting så mange ganger at det var nok å smile eller nikke eller gjenta ordene "i lufta" for slik å vise at "dette kjenner jeg igjen", "dette har jeg gjort til min sannhet" eller "dette er stoff jeg nå forholder meg til og kan mene noe om". Faglærer opplevde slik at stoffet ble mer aktivt virkende i undervisningssituasjonen. Dette står i kontrast til en situasjon som for eksempel kan være slik at man føler man ikke når gjennom med stoffet, verken på et forståelsesplan eller på et refleksjonsplan. Faglærer opplevde altså at stoffet ble brakt opp til et refleksjonsnivå gjennom a) studentenes aktive bruk av de digitale ressursene og b) klassens felles referanseramme som oppstod grunnet videodialogene. Dette økte refleksjonsnivået, og opplevelsen av å ha en felles referanseramme for stoffet, ga seg også utslag på både muntlig og skriftlig eksamen. Faglærer var eksaminator på muntlig eksamen, og kunne ta opp igjen og anvende de samme strategiene som var brukt i undervisningen. Studentene ble lett satt på sporet. Likeledes oppdaget vi på skriftlig eksamen at studentene hadde mange ulike ledetråder - men dette var ledetråder som faglærer kunne kjenne igjen fra konteksten i undervisningen i klasserommet.

\section{Utvikling av nøkkelordkomponenten}

Etter hvert som studentene deltok mer aktivt i undervisningen, ble det klart for faglærer at de manglet enkelte sentrale ord de trengte for å kunne uttrykke seg klart om tekstene. Studentene hadde behov for å kunne finne raskt fram til de ordene de ville trenge i en situasjon der de skulle snakke om tekstens kjerne. Det var for eksempel vanskelig å snakke om en litterær tekst som kretser rundt at en mann blir bitt av en giftig slange, hvis man ikke kunne eller husket ordet for slange. Faglærer utarbeidet derfor en liten kjerne av nøkkelord knyttet til hver tekst. Vi valgte å begrense oss til tolv ord for hver tekst. Disse ordene ble det fokusert spesielt på - både gjennom ansikt til ansikt-undervisning $o g$ i de digitale ressursene. I arbeidet med nøkkelordene ble vi faglærere også gjort mer bevisste på betydningen av kontekstinnlæring av ord. Vi erfarte at nye ord læres best gjennom at de innlæres i en sosial kontekst, og ikke gjennom "gammeldags pugging" - som er innlæring av ord trukket ut av den sammenhengen de naturlig inngår i. Denne overbevisningen - frambrakt og bekreftet gjennom arbeidet med de digitale ressursene - fikk altså innvirkning på hvordan vi fortsatte å videreutvikle de digitale ressursene. Nøkkelordene ble plukket ut av faglærer på bakgrunn av ulike kriterier. Ordene ble plukket ut a) i egenskap av å ha en symbolbærende funksjon i teksten b) fordi ordet var vanskelig - men likevel sentralt for forståelsen av teksten. Disse ordene ble trukket fram i undervisningssituasjonen. Ordene ble vist på lerret, og deretter snakker faglærer og studenter sammen - i en interaktiv dialog - om ordene. Målet var at studentene skulle bruke nøkkelordene i en setning for å bli mer bevisste både på ordenes semantiske betydning og deres betydning for forståelsen og tilegnelsen av teksten.

Gjennom å gjøre studentene bevisste på at det var enkelte ord de måtte lære seg tilknyttet hver av tekstene, ble også faglærers fokusering på hva som skulle være viktig, dreid inn i én retning: mot tekstens kjerne. Dette fokuset ble av faglærer oppfattet som konstruktivt og matnyttig. Studentene lot til å forstå hvor de måtte sette inn kreftene, istedenfor å føle 
avmakt i møtet med svært mange nye ord. Det lot til å være nødvendig for studentene å ha ledestjerner for hvor de skulle styre i arbeidet med de aktuelle tekstene. Nøkkelordene ble ikke bare "nye ord" de skulle lære seg; de ble også "innganger" for å kunne snakke om teksten og for å kunne huske sentrale momenter i teksten. Ordene ble forsøkt valgt med omhu, men faglærer merket seg underveis at det kreves en særskilt oppmerksomhet (og arbeid og erfaring med tekstene) for å kunne velge ut "de riktige" ordene. "De riktige" ordene i denne sammenhengen betyr de ordene som setter studentene "i gang"; "de riktige ordene" er de ordene som får studentene til å huske både ord og sammenhenger i teksten. Faglærer er av den oppfatning at nøkkelordene bør vurderes og revurderes nøye; det er en viktig jobb (og større jobb enn man kanskje ved første øyekast tror) å kunne velge "de riktige ordene". Likevel tror vi på potensialet av denne typen innfallsvinkel til en litterær tekst.

\section{Bruk av PowerPoint}

Når studentene hadde arbeidet seg igjennom tekstene ved hjelp av videodialogene, opplevde vi at de var mottakelige for mer stoff. Vi begynte derfor å utarbeide PowerPoint til bruk i selve undervisningssituasjonen. PowerPoint har blitt en integrert del av de fleste læreres arbeid- og presentasjonsform (jf Ørnes et.al. 2011), og i vårt tilfelle opplevde vi at vi måtte reflektere over vår bruk av dette presentasjonsverktøyet. Dette skyldes flere forhold, og vi stilte oss selv disse spørsmålene:

- Hvordan skal PowerPointen stilles opp i forhold til videodialogen? Skal PowerPointen følge innholdet for videodialogene eller skal PowerPointene fokusere på annet innhold som det ikke fokuseres på i videodialogene?

- Skal PowerPointene ha som mål å være stikkordsmessige og inneholde mange bilder?

Når det gjelder spørsmålet om hvordan PowerPointene skal stille seg i forhold til videodialogen, var det nødvendig for faglærer å gå inn i en prøveperiode for å finne fram til en passende form. Studentenes behov varierte også. Noen ønsket seg en tydelig repetisjon på bakgrunn av videodialogen, mens andre etterlyste en utfylling i forhold til videodialogen. Atter andre hadde ikke hørt på videodialogen, og følte behov for å få med seg "alt". Faglærers valg for utvikling av PowerPointene ble å gjøre disse så utfyllende som mulig (og ikke "repeterende" i forhold til videodialogene). PowerPointene forholdt seg altså ikke i nevneverdig grad til det som ble sagt på videodialogene. Faglærer opplevde at studentene jevnt over var mottakelige for mer stoff - nettopp fordi de hadde tilegnet seg annet grunnleggende stoff gjennom videodialogene. Slik ble PowerPointene altså en videreutvikling av videodialogene, og dette gjenspeilet denne dialogiske effekten som har blitt påpekt tidligere: både undervisningen og PowerPointene tok form i et samspill med videodialogene.

Vi forsøkte å utvikle PowerPointer med mange bilder og stikkord, og ikke for mange punkter per ark. Men denne framgangsmåten lot ikke til å være den mest egnede i denne sammenhengen. PowerPointenes gjenbruksverdi ble lavere (både for faglærer og for studentene), ettersom det var vanskelig å huske referanserammen knyttet til stikkordene utenfor selve undervisningssituasjonen, og fra et semester til et annet. I tillegg kommer det inn et ekstra moment når det gjelder å utvikle PowerPointer i undervisning på et fremmedspråk. Å ha for mange kulepunkter uten subjekt, verbal og objekt ser ut til å kunne påvirke studenter som er i en innlæringsfase av språket. Studentene trenger i den fasen de er i å ha hele setninger som modell for innlæringen. Av denne grunnen ble det også valgt å lage PowerPointer med hele setninger og med utfyllende informasjon.

\section{Påvirkning på undervisningsopplegg}

Da de digitale ressursene ble utviklet og var i sin spede begynnelse, var tanken at dette skulle gjøres for å lette studentenes arbeid med faget. I starten hadde vi ingen målsetning om at 
læreren skulle få en annerledes eller eventuelt enklere arbeidssituasjon. Underveis i prosessen og gjennom bruk av de digitale ressursene, oppdaget vi imidlertid at de digitale ressursene bidro til å forme lærerens undervisningsopplegg. Etter hvert som studentene kom inn i rutinen med å bruke de digitale ressursene, kunne faglærer merke at studentene stilte til timene med mer kunnskap enn hva de ville ha gjort hvis de kun hadde hatt den litterære teksten å forholde seg til. Dette medførte blant annet i:

- faglærer kunne gå raskere gjennom deler av stoffet

- faglærer kunne bruke videoene som referanse til det som ble presentert, og studentene hadde en annen forutsetning for å forstå de poeng faglæreren ville legge fram

- studentene lot til å ha lettere for å gå inn i en diskusjon; de refererte til videoen når de selv la fram sine tanker og punkter, og jobbet videre med egne tanker ut i fra dette

- studentene hadde også en større breddekunnskap på eksamen

- studentene deltok mer aktivt

Studentenes aktive deltakelse viste seg blant annet gjennom fokuset på nøkkelord. Studentene visste hvilken retning faglærer beveget seg når hun for eksempel trakk fram nøkkelordene. Denne forståelsen av "hvor vi skal gå" lot til å motivere studentene til aktiv deltakelse. For faglærer så det ut til at gjenkjennelsesøyeblikket ("dette har vi forstått før; dette kan vi noe om") stimulerte studentene til aktiv deltakelse. Andre studenter som kanskje følte mestring i forhold til nøkkelordene, tenderte til å fylle inn med nye momenter relatert til nøkkelordene. Gjennom dette stimulerte studentene hverandre til å gå videre og oppdage nye momenter i et samspill. Det å ha en forholdsvis klar retning for stoffet (gjennom nøkkelord, videodialoger med tydelig fokusering etc.) lot til å både a) motivere studenter til å uttrykke det de hadde forstått / sette ord på kunnskap som kanskje ellers ville ha vært "taus kunnskap" og b) motivere for eksempel studenter med spansk som morsmål til å bidra i dialogen gjennom å bli "satt på sporet" av medstudenters aktive deltakelse og vilje til å gå inn i teksten.

\section{Konklusjon}

I denne artikkelen har vi sett at innføring av videodialoger påvirket studentene på en positiv måte: de fikk et verktøy som hjalp dem til å tilegne seg lærestoffet i større grad en tidligere. For å utnytte potensialet i dette verktøyet, måtte studentene endre sin praksis slik at de fikk integrert verktøyet som en del av sin læringsprosess. Vi så at vi i første omgang måtte gjøre det obligatorisk å bruke videodialogene for at studentene skulle oppdage nytten av disse. Resultatet av dette ble at studentene møtte bedre forberedt til undervisningen og dermed også kunne delta mer aktivt i timene. Dette førte igjen til at faglærer justerte sitt undervisningsopplegg og oppdaget nye behov hos studentene. For å dekke disse behovene, oppstod ideer til nye digitale ressurser: satsingen på videodialogen frambrakte nøkkelordfunksjonen og dette i sammenheng med undervisningen la føring for hvordan PowerPointen ble utformet.

Vi synes at vi kan se et mønster: Digitale ressurser som blir utviklet med en klar satsing og med et klart fokus for studentene gir struktur for undervisningen. Strukturen som dannes i undervisningen og arbeidet med de digitale ressursene gir utgangspunkt for ideer til nye digitale ressurser. For oss synes det å være nødvendig at man satser på ett eller få verktøy om gangen, og ikke på mange samtidig. Det later også til å stå som sentralt at studentene må ha en klar og tydelig innføring i bruken av ressursene i tillegg til at de digitale læringsressursene må inngå som en integrert del av undervisningen. Når ressursene på nett samspiller med det som skjer i klasserommet slik at de utfyller hverandre, først da får IKT en merverdi og vi kan si at "blended learning" bidrar til økt kvalitet i undervisningen. Vi har 
også sett at når de digitale ressursene integreres med ansikt-til-ansikt undervisningen, så påvirker de ulike delene av undervisningen hverandre.

For at digitale læringsressurser skal kunne bidra til økt studentaktivitet i klasserommet, er det nødvendig at ressursene blir integrert som en del av undervisningen slik at de står i et dialogisk forhold mellom lærer, studenter og undervisningen i klasserommet. Når ressursene støtter opp om studentenes læringsarbeid og inngår i deres studiepraksiser, vil studentene møte mer forberedt til undervisningen og dermed også kunne delta mer aktivt. En større grad av deltakelse, vil igjen skape økt motivasjon og en opplevelse av kvalitet i undervisningen.

\section{Litteraturliste}

Bruke for referanse: Forfatter. (år). Artikkeltittel. I Redaktør, redaktør, redaktør (Red.), Bokas tittel i kursiv (sidespenn). Utgivelsessted: Forlag.

Bjørke, C. (2014) Vokabular og ordinnlæring. I Bjørke, C., Dypedahl, M. \& Myklevold, G.A. (Red.), Fremmedspråksdidaktikk. Oslo: Cappelen Damm Akademisk, s. 72-86.

Carter, R. \& Long, M. N. (1991) Why literature? Teaching Literature. Essex: Longman

Drange, E.-M. \& Tønnessen, E. S. (under arbeid). Use of multimodal digital resources in foreign language learning.

Garrison, R. \& Kanuka, H. (2004) Blended learning: Uncovering its transformative potential in higher education. Internet and Higher Education 7 , 95-105.

Ginns, P. \& Ellis, R. (2007) Quality in blended learning: Exploring the relationships between on-line and face-to-face teaching and learning. Internet and Higher Education 10, 53-64.

Granberg, C. (2011). ICT and learning in teacher education. The social construction of pedagogical ICT discourse and design. (Doktorgradsavhandling fra Universitetet $\mathrm{i}$ Umeå). Hentet fra: http://www.diva-portal.org/smash/get/diva2:414445/FULLTEXT03

Halliday, M.A.K. (1989). Spoken and Written Language. Oxford: Oxford University Press.

Hansejordet, I. (2012). "La marginación de la literatura y de Hispanoamérica en el español como lengua extranjera". Nordic Journal of Modern Language Methodology, Vol 1, No 1. Hentet fra: http://journal.uia.no/index.php/NJMLM/article/view/33/22\#.VH7bSTGG8b0

Krashen, S. (1985). The input hypothesis: issues and implications. London: Longman

Krashen, S. (1987). Principles and practice in second language acquisition. London: Prentice-Hall International.

Kunnskapsdepartemenet (uå) "Satsingsområder” Tilgjengelig på: http://www.regjeringen.no/upload/KD/Vedlegg/UH/Bologna/10\%20satsningsomr $\% \mathrm{C} 3 \%$ A5der bologna.pdf (29.10.13)

Kunnskapsdepartementet (2011) Nasjonalt kvalifikasjonsrammeverk for livslang læring Tilgjengelig på:

http://www.regjeringen.no/upload/KD/Vedlegg/Kompetanse/NKR2011mvedlegg.pdf $(29.10 .13)$

López-Pérez, M. V., Pérez-López, M. C. \& Rodríguez, A. L. (2011). Blended learning in higher education: Student's perceptions and their relation to outcomes. Computers \& Education 56, 818-826.

Lønn, C. \& Drange, E.-M. D. (2013). ’Litteratur på nett” Om utvikling av digitale læringsressurser til bruk i litteraturundervisning på spansk. Nordic Journal of Modern Language Methodology, Vol 2, No 1. Hentet fra:

http://journal.uia.no/index.php/NJMLM/article/view/97 
Ørnes, H., Wilhelmsen, J., Breivik, J. \& Solstad, K. J. (2011) Digital tilstand i høyere utdanning 2011. Norgesuniversitetets monitor. Norgesuniversitetets skriftserie nr. 1/2011. Tromsø: Lundblad Media A/S. 